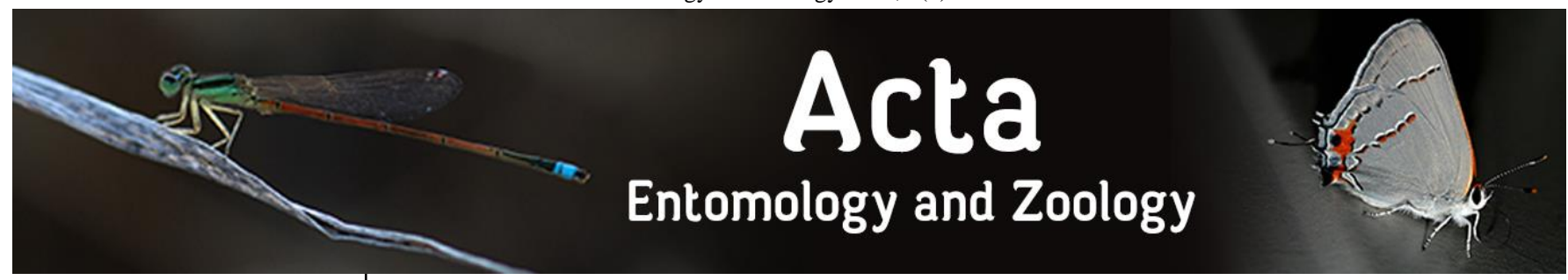

E-ISSN: 2708-0021 P-ISSN: 2708-0013 www.actajournal.com AEZ 2021; 2(1): 115-122 Received: 17-12-2020

Accepted: 22-01-2021

Kari Iamba

PNG University of Natural Resources \& Environment, Private Mail Bag, Department of Agriculture, Vudal, Papua New Guinea

\section{Moses Waiviro}

PNG University of Natural Resources \& Environment, Private Mail Bag, Department of Agriculture, Vudal, Papua New Guinea
Corresponding Author: Kari Iamba

PNG University of Natural Resources \& Environment, Private Mail Bag, Department of Agriculture, Vudal, Papua New Guinea

\section{Concentration effects of chili and ginger extracts against diamondback moth (Plutella xylostella L.) on round cabbage}

\section{Kari Iamba and Moses Waiviro}

DOI: https://doi.org/10.33545/27080013.2021.v2.i1b.36

\begin{abstract}
Diamondback moth (Plutella xylostella L.) is a major pest of cabbage and other vegetables in the Brassicaceae family. The management and control of this cosmopolitan and economic pest has been a challenge in tropical regions. Reliance on chemical insecticides have led to resistance, natural enemy suppression, contaminated residues, risks to chemical poisoning and other environmental contamination. Therefore, the need to utilize non-host spice plants is an alternative. For this study, we focus on different concentration levels of two local spice plants; (1) chili (Capsicum frutescens L.) and (2) ginger (Zingiber officinale R.). Based on previous studies, extracts from both plants have been able to reduce pest infestation in vegetables. There were nine (9) treatments $(\mathrm{T}): \mathrm{T}_{1}=3 \mathrm{ml}$ of chili extract $\mathrm{L}^{-1}$ $v / v, \mathrm{~T}_{2}=6 \mathrm{ml}$ of chili extract $\mathrm{L}^{-1} v / v, \mathrm{~T}_{3}=9 \mathrm{ml}$ of chili extract $\mathrm{L}^{-1} v / v, \mathrm{~T}_{4}=3 \mathrm{ml}$ of ginger extract $\mathrm{L}^{-1} v / v$, $\mathrm{T}_{5}=6 \mathrm{ml}$ of ginger extract $\mathrm{L}^{-1} v / v, \mathrm{~T}_{6}=9 \mathrm{ml}$ of ginger extract $\mathrm{L}^{-1} v / v, \mathrm{~T}_{7}=3 \mathrm{ml}$ of pure water $\mathrm{L}^{-1} v / v$, $\mathrm{T}_{8}=6 \mathrm{ml}$ of pure water $\mathrm{L}^{-1} v / v$ and $\mathrm{T}_{9}=9 \mathrm{ml}$ of pure water $\mathrm{L}^{-1} v / v$. From these treatments, $6 \mathrm{ml}$ chili was effective in lowering the defoliation $(\%)$ and was able to produce high leaf area index (LAI) regardless of increasing rainfall. Ginger $9 \mathrm{ml}$ produced high LAI and low defoliation in spite of increasing rainfall. Rainfall (mm) was an important environmental factor affecting the abundance, LAI and defoliation.
\end{abstract}

Keywords: Plutella xylostella L., Capsicum frutescens L, Zingiber officinale R, leaf area index, defoliation, abundance

\section{Introduction}

Diamondback moth (Plutella xylostella L.) is a major pest of cabbage and other vegetables in the Brassicaceae family. P. xylostella is a cosmopolitan and important economic pest in tropical regions and globally (Zhang et al. 2016) ${ }^{[41]}$. Use of chemical pesticides have led to resistance, natural enemy suppression, contaminated residues, risks to chemical poisoning and other environmental contamination (Obeng-Ofori \& Ankrah 2002; Timbilla \& Nyarko 2004; Ntow et al. 2006; Fening et al. 2011; Iamba \& Malapa 2020) ${ }^{[31,40,30,12,17]}$. The moth is a destructive pest at Vudal and throughout East New Britain Province (Iamba \& Yoba $2019)^{[20]}$. The focus in controlling $P$. xylostella has now shifted from chemical to botanical pesticides that have repellent and deterrent effect (Coulibaly et al. 2002) ${ }^{[8]}$. Plants that have insecticidal properties can be sourced locally and thus provides a low-cost technique to manage insect pests (Iamba \& Masu 2020) ${ }^{[21]}$. Extracts from leaves, flowers, fruits and seeds of insecticidal plants have been applied to repel ovipositing females, reduce feeding activity and cause larval mortality of $P$. xylostella on treated cabbage leaves (Shin-Foon \& Yu-Tong 1993; Chen et al. 1996; Charleston et al. 2005; Abbasipour et al. 2010) ${ }^{[38,7,6,1]}$. Botanical pesticide is an essential input in any plant protection program since they encourage the activity of natural enemies to supress pests (Gentz et al. 2010) ${ }^{[13]}$. A push-pull system exists when non-host plant extracts are applied to reduce oviposition of insect pest while enhancing the activity of parasitoids in crops (Liu et al. 2007) ${ }^{[26]}$. Various semiochemicals are involved in a push-pull system which can repel pests, attract natural enemy populations or lure both counterparts to meet (Pyke et al. 1987; Miller \& Cowles 1990; Pickett et al. 1997; Agelopoulos et al. 1999) [33, 28, 32,3].

For this study, we focus on different concentration levels of two local spice plants; (1) chili (Capsicum frutescens L.) and (2) ginger (Zingiber officinale R.). Extracts from both plants were able to reduce pest infestation in vegetables and crops (Iamba \& Yoba 2019; Iamba \& Malapa 2020; Iamba \& Masu 2020) ${ }^{[20,21] .}$ 
The aim is to determine the concentration level of the two extracts that can effectively suppress the activity of $P$. xylostella on round cabbage (Oleracea var. capitata). Round cabbage (O. var. capitata) is highly susceptible to attack of $P$. xylostella in Vudal agroecosystem. From previous studies, chili (C. frutescens) extract has been utilized as an effective control of $P$. xylostella due to its antifeedant and deterrent properties (Iorizzi et al. 2000; Khan et al. 2000; Iamba \& Yoba 2019) ${ }^{[23,25,20]}$. Cabbages treated with chili and other botanical extracts produced comparable yield (Begna \& Damtew 2015) ${ }^{[5]}$. A high infestation in control treatment (no extract) was evident due to absence of barrier against feeding larvae of $P$. xylostella (Reuben et al. 2006; Iamba \& Malapa 2020) ${ }^{[34,21]}$. On the other hand, Ginger $(Z$. officinale) contains repellent properties and has been effective in repelling Dipteran insects such as Culex tritaeniorhynchus and Anopheles subpictus) (Govindarajan 2011) ${ }^{[14]}$. Ginger extract inhibited the emergence of adult $C$. cramerella, therefore it was recommended for application (Saripah et al. 2019) ${ }^{[37]}$. Several studies have shown that the volatile chemical constituents from extract of $Z$. officinale deterred insect pests (Escoubas et al. 1995; Agarwal et al. 2001) ${ }^{[10,2]}$.

\section{Materials and Methods}

\section{(a) Study site}

The study was carried out at the academic crops section at PNG University of Natural Resources and Environment (PNG UNRE) campus in East New Britain, Papua New Guinea (PNG). The experimental site is located $51 \mathrm{~m}$ above sea level approximately at $4^{\circ} 21^{\prime} 01.90^{\prime \prime} \mathrm{S}$ and $152^{\circ} 00^{\prime}$ 33.44" E (Iamba \& Yoba 2019; Iamba \& Yoba 2020) ${ }^{[20,21] .}$ The academic crops section is an experimental site allocated for research studies especially on tropical crops. PNG UNRE is an Agricultural and Environmental institution that supports the sustainable management of natural resource in Agriculture, Fisheries, Forestry and Animal Sciences. The soil type is sandy loam, well-drained, fertile, calcareous and generally alkaline in nature (Iamba \& Yaubi 2021) ${ }^{[22]}$. Sandy loam soil possess good binding traits and has extensively been used as an adequate medium for raising seedlings (Howcroft 2002) ${ }^{[16]}$. With sandy loam soils, soil sterilization is not mandatory except if infection occurs. The climate is classified as tropical with a great deal of rainfall experienced all year round even in the driest month. The atmosphere is mostly humid with an average rainfall of $2780 \mathrm{~mm}$ per annum and a mild dry season. The average daily humidity ranges from $77-79 \%$ with temperature of 27 $29{ }^{\circ} \mathrm{C}$ (Iamba et al. 2021) ${ }^{[22]}$. According to Howcroft $(2002)^{[16]}$, these environmental conditions are highly suitable for tree cultivation such as balsa and other crops as well.

\section{(b) Nursery}

A nursery was established prior to the study by sowing of cabbage seeds in nursery trays at the nursery house. The variety of round cabbage (Oleracea var. capitata) used for this study is $\mathrm{K}-\mathrm{K}$ cross. $\mathrm{K}-\mathrm{K}$ Cross is an improved mediumsized hybrid of Oleracea var. capitata which is popular in tropical and sub-tropical countries because of its high heat tolerance and early maturity (58 days after transplant). Approximately 300 seeds were sown while experimental plots were constructed in the field. Cabbage seedlings were nurtured for three (3) weeks in the nursery house to ensure acclimatization before transplanting. Acclimatization process was done to habituate the seedlings to the field environmental conditions. Seedlings that are raised in nursery have higher chance of survival than direct sown seeds. Due to acclimatization process, they can withstand the harsh weather conditions when transplanted into field experimental plots.

\section{(c) Experimental design}

Site clearance and plot preparation occurred three (3) weeks prior to nursery phase to allow for solarization. Bushes were cleared, soil tilled and unwanted weeds were removed. Proper drainages were constructed to remove excessive water and to avoid any possibility of waterlog conditions. The prepared plots were divided into experimental plots following a Complete Randomized Block design (CRBD). The plot size, planting distance and plant density followed standard measurements in cabbage cultivation (Iamba \& Yaubi 2021) ${ }^{[22]}$. Each plot had a dimension of $2 \times 2 \mathrm{~m}\left(4 \mathrm{~m}^{2}\right)$ with a spacing of $40 \mathrm{~cm}$ between plants and $50 \mathrm{~cm}$ between rows. Therefore, each plot had a plant density of 20 plants per plot $\left[\left(4 \mathrm{~m}^{2} /(0.4 \times 0.5)\right]\right.$. There were nine (9) treatments (T): $\mathrm{T}_{1}=3 \mathrm{ml}$ of chili extract $\mathrm{L}^{-1} v / v, \mathrm{~T}_{2}=6 \mathrm{ml}$ of chili extract $\mathrm{L}^{-1} v / v, \mathrm{~T}_{3}=9 \mathrm{ml}$ of chili extract $\mathrm{L}^{-1} v / v, \mathrm{~T}_{4}=3 \mathrm{ml}$ of ginger extract $\mathrm{L}^{-1} v / v, \mathrm{~T}_{5}=6 \mathrm{ml}$ of ginger extract $\mathrm{L}^{-1} v / v, \mathrm{~T}_{6}=9 \mathrm{ml}$ of ginger extract $\mathrm{L}^{-1} v / v, \mathrm{~T}_{7}=3 \mathrm{ml}$ of pure water $\mathrm{L}^{-1} v / v, \mathrm{~T}_{8}=6 \mathrm{ml}$ of pure water $\mathrm{L}^{-1} v / v$ and $\mathrm{T}_{9}=9 \mathrm{ml}$ of pure water $\mathrm{L}^{-1} v / v$. Each concentration level (treatment) was replicated three times. There were total of twenty-seven (27) experimental plots pertaining to 9 treatments $\times 3$ replicates. Chili and ginger extract was selected based on their repellent and deterrent properties. A control treatment (pure water) was included and used as a reference group for comparison. During the experimental phase, there was no chemical insecticide or pesticide used nor any chemical fertilizers because the objective was to test the sole effect of the plant extracts.

\section{(d) Plant content extraction}

The stalks of ripened chili and the outer cover of the cloves of ginger were removed. Ginger was further grated using a kitchen grater to produce fine material. Both plant materials were dried in the sun for 2 weeks to remove most moisture content. Then they were grounded separately using an electric blender. About $2.5 \pm 0.5 \mathrm{~kg}$ of each grounded material were obtained using an electronic balance and placed in two separate desiccators. About $500 \mathrm{ml}$ of $75 \%$ ethanol $\left(\mathrm{C}_{2} \mathrm{H}_{6} \mathrm{O}\right)$ was added to each desiccator and covered tightly. The desiccator prevented evaporation of ethanol and protected the hygroscopic contents to react with water from humidity. The contents were left on a designated lab bench for 7 days ( 1 week) in order to allow the ethanol to degrade the cell walls of the materials thus releasing the chemical constituents. After 1 week, the resultant mixtures were sieved separately using a filter paper and the filtrate collected in $500 \mathrm{ml}$ beakers. As suggested by Fening et al. (2013) ${ }^{[11]}$, a few drops of natural oil and soap were added to the mixture to enhance its delivery and adhesiveness on the leaf surface. The mixtures were stored in separate $1 \mathrm{~L}$ containers with polyseal ('P') lids to prevent evaporation. Then $3 \mathrm{ml}, 6 \mathrm{ml}$ and $9 \mathrm{ml}$ of each mixture was diluted in $1 \mathrm{~L}$ of water and sprayed using nine (9) separate hand sprayers.

\section{(e) Sampling}

Data was collected three days after spraying and three 
weeks after transplanting. Three (3) response variables were measured: (1) abundance, (2) defoliation (\%) and (3) leaf area index (LAI). These variables were used to calculate the efficacy of each treatment on P. xylostella. The procedure and protocol used were similar to the ones used by Iamba and Yaubi (2021) ${ }^{[22]}$. The abundance was basically the number of $P$. xylostella caterpillar counted during each sampling time. Caterpillars were observed with less disturbance especially when opening cabbage leaves for counting. Both the leaf area index (LAI) and defoliation (\%) were obtained using an application called the BioLeaf Foliar Analysis in an android phone. A sample of leaf was placed against a white paper, and a clear shot of 13-megapixel resolution was taken with the phone camera. The app did all scanning and processing of defoliation (\%) and LAI. Data pertaining to each response variable was collected twice per week for a total period of 3 weeks. Three plants were randomly selected per plot and measurements on the 3 variables were recorded in a field datasheet. There were 243 data points collected per sampling time (27plots x 3 plants per plot x 3 variables per plant). Since data was collected twice per week, a total of 486 data points were recorded per week. Therefore in three weeks of sampling, a grand total of 1,458 data were recorded. Rainfall data was collected from the university weather station at Vudal and a weekly (5 days) average was computed and used for analysis.

\section{(e) Data analysis}

The data on response variables showed asymmetric pattern meaning they were not normally distributed according to Shapiro-Wilk test $(p<0.05)$. To correct the skewness in data distribution, Generalized Linear Model (GzLM) was used. The data were log transformed and analysed using the Poisson exponential family function (link $=\log$ ) in RStudio (version 4.0.3). Since Poisson had a lower Akaike's information criterion (AIC), it was more suitable to use than Gamma exponential family. As an estimator and statistical criteria, the AIC estimated the quality of both models. The root-mean-square error (RMSE) as a measure of Maximum Likelihood Estimation (MLE) was also used in estimating the Poisson model. The RMSE in Poisson model (RMSE=7.07) was lower than linear model (RMSE=104.24) across all tested variables therefore Poisson GzLM family was chosen as a suitable model for data analysis. RMSE measured the difference between predicted values and the actual values (error term). The lower the error term, the better the predictor model fits to the actual values (minimize error). Although mean and variance are known as distribution parameters for normal distribution, Poisson distribution is governed by one parameter - lambda $(\lambda)$, which is the total number of events $(\mathrm{k})$ divided by the number of units (n) in the data $(\lambda=\mathrm{k} / \mathrm{n})$. Data were fed into this Poisson model: $\log (y)=\alpha+\beta_{1} x_{1}+\beta_{2} x_{2}+\ldots .+\beta_{p} x_{p}$, where $y$ is the response variable, $\alpha$ and $\beta$ are numeric coefficients, $\alpha$ being the intercept (sometimes by $\beta_{0}$ ), and $x$ is the predictor/explanatory variable. As aforementioned, coefficients were calculated using the MLE method. All graphs relating to abundance, defoliation and LAI were constructed with ggplot2 package. Tukey Honest Significant Difference test (Tukey HSD) separated the means of each treatment and concentrations. Cross-factor analyses was also done to test the interaction of plant extracts and concentrations ( $\mathrm{ml}$ ) on abundance, defoliation and LAI. For graphical presentation of the factor analyses, cowplot package was integrated with ggplot 2 and executed in RStudio.

\section{Results}

A total of 1,458 data points were recorded within three weeks of sampling. The diamondback moth caterpillars $(P$. xylostella) varied in their responses to different concentration levels of extracts. As shown in Table 1, the abundance of $P$. xylostella in $\mathrm{T}_{1}$ ( $3 \mathrm{ml}$ of chili extract $\mathrm{L}^{-1} v / v$ ) $(5.37 \pm 1.20, p<0.05)$ was significantly higher than in $\mathrm{T}_{2}$ $\left(6 \mathrm{ml}\right.$ of chili extract $\left.\mathrm{L}^{-1} v / v\right)(4.59 \pm 0.81, p>0.05)$ and $\mathrm{T}_{3}$ $\left(9 \mathrm{ml}\right.$ of chili extract $\left.\mathrm{L}^{-1} v / v\right)(3.96 \pm 1.31, p>0.05)$. There was no significant difference between $\mathrm{T}_{2}$ and $\mathrm{T}_{3} \quad(p>0.05)$. Abundance in $\mathrm{T}_{4}\left(3 \mathrm{ml}\right.$ of ginger extract $\left.\mathrm{L}^{-1} v / v\right)(5.52 \pm 0.84$, $p>0.05)$ was statistically similar to $\mathrm{T}_{5}(6 \mathrm{ml}$ of ginger extract $\left.\mathrm{L}^{-1} v / v\right)(5.52 \pm 0.83, p>0.05)$. Abundance in $\mathrm{T}_{6}(9 \mathrm{ml}$ of ginger extract $\left.\mathrm{L}^{-1} v / v\right)$ was significantly lower $(3.76 \pm 0.73$, $p<0.05)$. The abundance was not statistically significant in $\mathrm{T}_{7}\left(3 \mathrm{ml}\right.$ of pure water $\left.\mathrm{L}^{-1} v / v\right)(3.98 \pm 0.73, p>0.05), \mathrm{T}_{8}(6 \mathrm{ml}$ of pure water $\left.\mathrm{L}^{-1} v / v\right)(3.31 \pm 0.56, p>0.05)$ and $\mathrm{T}_{9}(9 \mathrm{ml}$ of pure water $\left.\mathrm{L}^{-1} v / v\right)(3.78 \pm 0.70, p>0.05)$. Control treatment (pure water) did not influence the abundance of $P$. xylostella caterpillars.

Table 1: The concentrations (Conc.) were used as treatments in this study. Ginger extract protected cabbage plants at high concentration $\left(9 \mathrm{mlL}^{-1}\right)$ while chili did so at low concentration $\left(6 \mathrm{mlL}^{-1}\right)$. Control concentrations did not differ significantly in terms of abundance, LAI and defoliation $(\%)$.

\begin{tabular}{|c|c|c|c|c|c|c|c|c|}
\hline \multirow{2}{*}{$\begin{array}{c}\text { Plant } \\
\text { extracts }\end{array}$} & \multirow[t]{2}{*}{ Conc. } & \multirow{2}{*}{$\pm \mathbf{N}$} & \multicolumn{2}{|c|}{ Abundance } & \multicolumn{2}{|c|}{ Leaf area index (LAI) } & \multicolumn{2}{|c|}{ Defoliation (\%) } \\
\hline & & & ${ }^{\dagger}$ mean \pm SE & ${ }^{4} \mathrm{SD}$ & mean \pm SE & ${ }^{4} \mathrm{SD}$ & ${ }^{\dagger}$ mean \pm SE & ${ }^{4} \mathrm{SD}$ \\
\hline \multirow{3}{*}{ Chili } & $3 \mathrm{ml}$ & 54 & $5.37 \pm 1.20 \mathrm{a}$ & 8.84 & $6.49 \pm 0.39 \mathrm{bc}$ & 2.90 & $2.69 \pm 0.36 \mathrm{abc}$ & 2.66 \\
\hline & $6 \mathrm{ml}$ & 54 & $4.59 \pm 0.81 \mathrm{ab}$ & 5.96 & $7.40 \pm 0.44 \mathrm{a}$ & 3.26 & $2.02 \pm 0.37 \mathrm{c}$ & 2.72 \\
\hline & $9 \mathrm{ml}$ & 54 & $3.96 \pm 1.31 \mathrm{ab}$ & 9.64 & $6.39 \pm 0.29 \mathrm{c}$ & 2.19 & $2.39 \pm 0.38 \mathrm{bc}$ & 2.77 \\
\hline \multirow[t]{3}{*}{ Control } & $3 \mathrm{ml}$ & 54 & $3.98 \pm 0.73 \mathrm{ab}$ & 5.37 & $7.22 \pm 0.43 \mathrm{a}$ & 3.16 & $2.10 \pm 0.27 \mathrm{c}$ & 1.98 \\
\hline & $6 \mathrm{ml}$ & 54 & $3.31 \pm 0.56 \mathrm{~b}$ & 4.09 & $7.32 \pm 0.45 \mathrm{a}$ & 3.33 & $2.46 \pm 0.28 \mathrm{bc}$ & 2.08 \\
\hline & $9 \mathrm{ml}$ & 54 & $3.78 \pm 0.70 \mathrm{~b}$ & 5.15 & $7.13 \pm 0.43 \mathrm{ab}$ & 3.13 & $2.64 \pm 0.29 a b c$ & 2.16 \\
\hline \multirow[t]{3}{*}{ Ginger } & $3 \mathrm{ml}$ & 54 & $5.52 \pm 0.84 \mathrm{a}$ & 6.18 & $6.38 \pm 0.42 \mathrm{c}$ & 3.11 & $3.39 \pm 0.40 \mathrm{a}$ & 2.95 \\
\hline & $6 \mathrm{ml}$ & 54 & $5.52 \pm 0.83 \mathrm{a}$ & 6.12 & $6.47 \pm 0.40 \mathrm{c}$ & 2.96 & $3.06 \pm 0.42 \mathrm{ab}$ & 3.11 \\
\hline & $9 \mathrm{ml}$ & 54 & $3.76 \pm 0.73 \mathrm{~b}$ & 5.35 & $7.22 \pm 0.39 \mathrm{a}$ & 2.91 & $2.18 \pm 0.31 \mathrm{c}$ & 2.26 \\
\hline $\begin{array}{l}\text { T repr } \\
\dagger \text { Mean } \\
\text { tStand }\end{array}$ & D & & uency of & & ariable. & & & \\
\hline
\end{tabular}


Leaf area index (LAI) in $3 \mathrm{ml}(6.49 \pm 0.39, p>0.05)$ and $9 \mathrm{ml}$ $(6.39 \pm 0.29, p>0.05)$ chili extract did not differ significantly. However an increase in LAI was noted at $6 \mathrm{ml}$ chili which is considered as medium concentration $(7.40 \pm 0.44, p<0.05)$ (table 1). All concentration levels of control treatment did not show any significant changes in LAI $(p>0.05)$. Defoliation (\%) in $3 \mathrm{ml}, 6 \mathrm{ml}$ and $9 \mathrm{ml}$ of chili extract were not statistically significant $(p>0.05)$ however they were lower than $3 \mathrm{ml}$ and $6 \mathrm{ml}$ of ginger extract $(p<0.05)$. All concentrations of control treatment did not record at significant changes in defoliation $(p>0.05)$ (table 1$)$. Distinct differences were notable in ginger extract where $9 \mathrm{ml}(2.18 \pm 0.31, p<0.05)$ had lower defoliation than $3 \mathrm{ml}$ $(3.39 \pm 0.40, p>0.05)$ and $6 \mathrm{ml}(3.06 \pm 0.42, p>0.05)$ (table 1).

For comparison across treatments, the abundance did not differ between $3 \mathrm{ml}$ chili and the two ginger concentrations, $3 \mathrm{ml}$ and $6 \mathrm{ml}$ (fig. 1). The abundance in $6 \mathrm{ml}$ ginger is significantly higher than that of chili and control $(p<0.05)$. Abundance across $9 \mathrm{ml}$ of chili, ginger and control were similarly low $(p>0.05)$. Low abundance of $P$. xylostella was achieved with $9 \mathrm{ml}$ chili and $9 \mathrm{ml}$ ginger (fig. 1A). LAI in $3 \mathrm{ml}$ chili and ginger were statistically similar $(p>0.05)$ while $6 \mathrm{ml}$ chili produced higher LAI than that of ginger $(p<0.05)$. However, $9 \mathrm{ml}$ ginger produced higher LAI than $9 \mathrm{ml}$ chili $(p>0.05)$. LAI in all concentration levels of control did not differ significantly $(p>0.05)$. High LAI was achieved with $6 \mathrm{ml}$ chili and $9 \mathrm{ml}$ ginger extract (fig. 1B). Defoliation $(\%)$ was high in $3 \mathrm{ml}$ ginger $(p<0.05)$ compared to chili and control treatments. Chili $6 \mathrm{ml}$ recorded low defoliation $(\%)$ than control and ginger extracts $(p<0.05)$. Defoliation in $9 \mathrm{ml}$ chili was similar to that of control treatment $(p>0.05)$. There was a decrease in defoliation at $6 \mathrm{ml}$ however the decline was significant in $9 \mathrm{ml}$ ginger $(p<0.05)$.

\section{Response of Plutella xylostella to different concentrations of plant extracts}
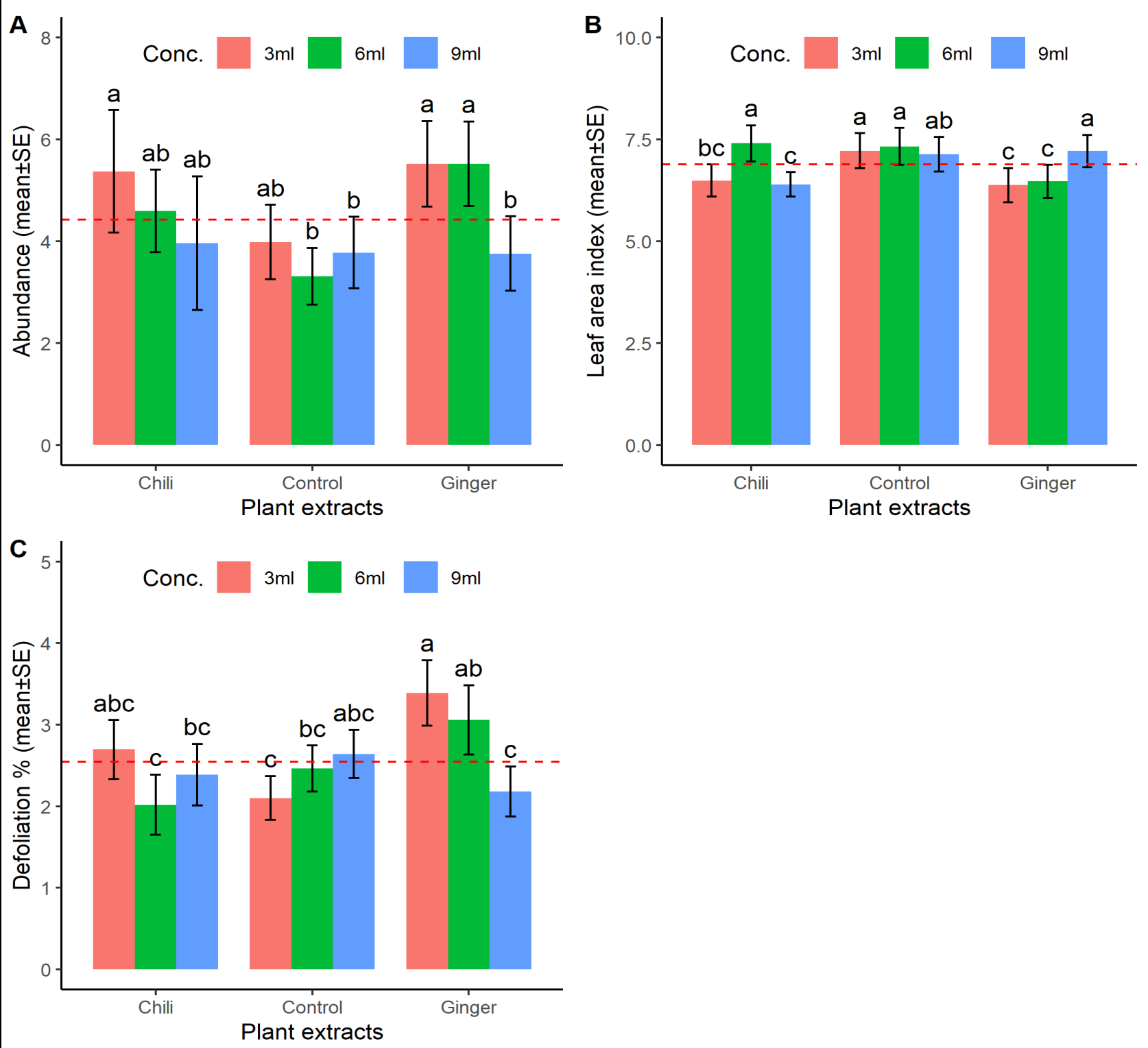

Fig 1: Plutella xylostella responses in terms of abundance, LAI and defoliation (\%) varied in the three concentration levels. The control treatment generally had low abundance. Both $6 \mathrm{ml}$ and $9 \mathrm{ml}$ of chili showed lower abundance. Same can be seen in ginger except a significant decrease at $9 \mathrm{ml}$. All concentrations of control did not differ in terms of LAI. LAI increased at $6 \mathrm{ml}$ chili $(p<0.05)$ while decreased at $3 \mathrm{ml}$ and $9 \mathrm{ml}$. Ginger $9 \mathrm{ml}$ showed increased LAI while corresponding defoliation (\%) decreased. Chili and control levels had low defoliation except in $6 \mathrm{ml}$ chili $(p<0.05)$. The horizontal dotted line represents the overall mean: (A) $\mu=4.42$, (B) $\mu=6.89$ and (C) $\mu=2.55$. 


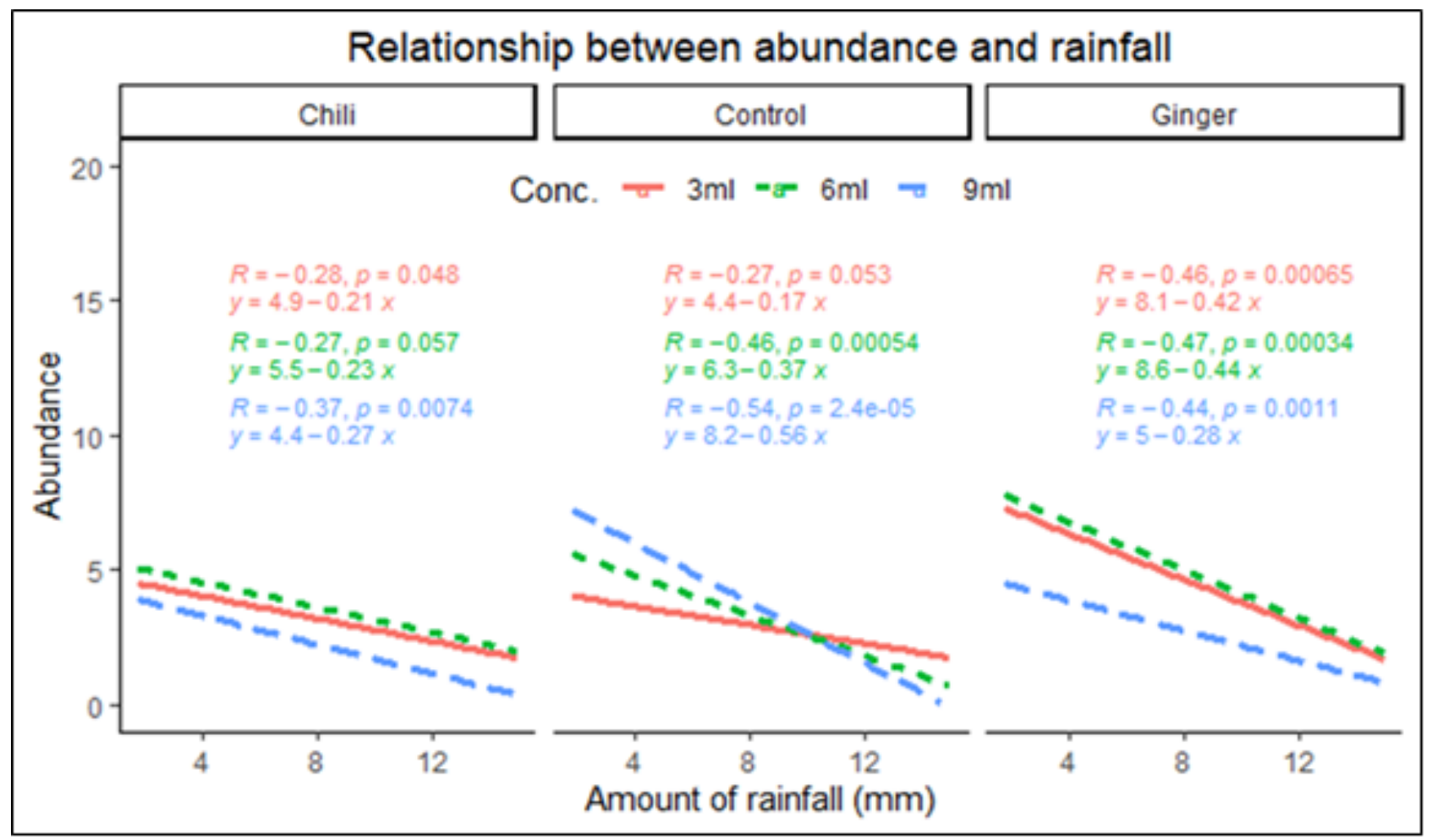

Fig 2: Abundance of $P$. xylostella was negatively correlated with rainfall. There was a decreasing trend in terms of abundance in chili, ginger and control treatments as a function of rainfall $(\mathrm{mm})$. All relationships were created using Pearson correlation $(\mathrm{R})$ with $\mathrm{p}$-values indicating the level of statistical significance at $\alpha=0.05$.

It was noted that as the amount of rainfall $(\mathrm{mm})$ increased, the abundance of $P$. xylostella caterpillars decreased (fig. 2). There was a significant negative correlation between $9 \mathrm{ml}$ chili and abundance $(p<0.05, \mathrm{r}=-0.37)$. Chili $6 \mathrm{ml}$ did not have any significant correlation while a weak negative correlation was noted in $3 \mathrm{ml}$ chili. A significant inverse relationship was evident in $6 \mathrm{ml}$ and $9 \mathrm{ml}$ control treatments. All concentration levels of ginger had significant negative correlation with abundance: $3 \mathrm{ml}(p<0.05, \mathrm{r}=-0.46), 6 \mathrm{ml}$ $(p<0.05, \mathrm{r}=-0.47)$ and $9 \mathrm{ml}(p<0.05, \mathrm{r}=-0.44)$.

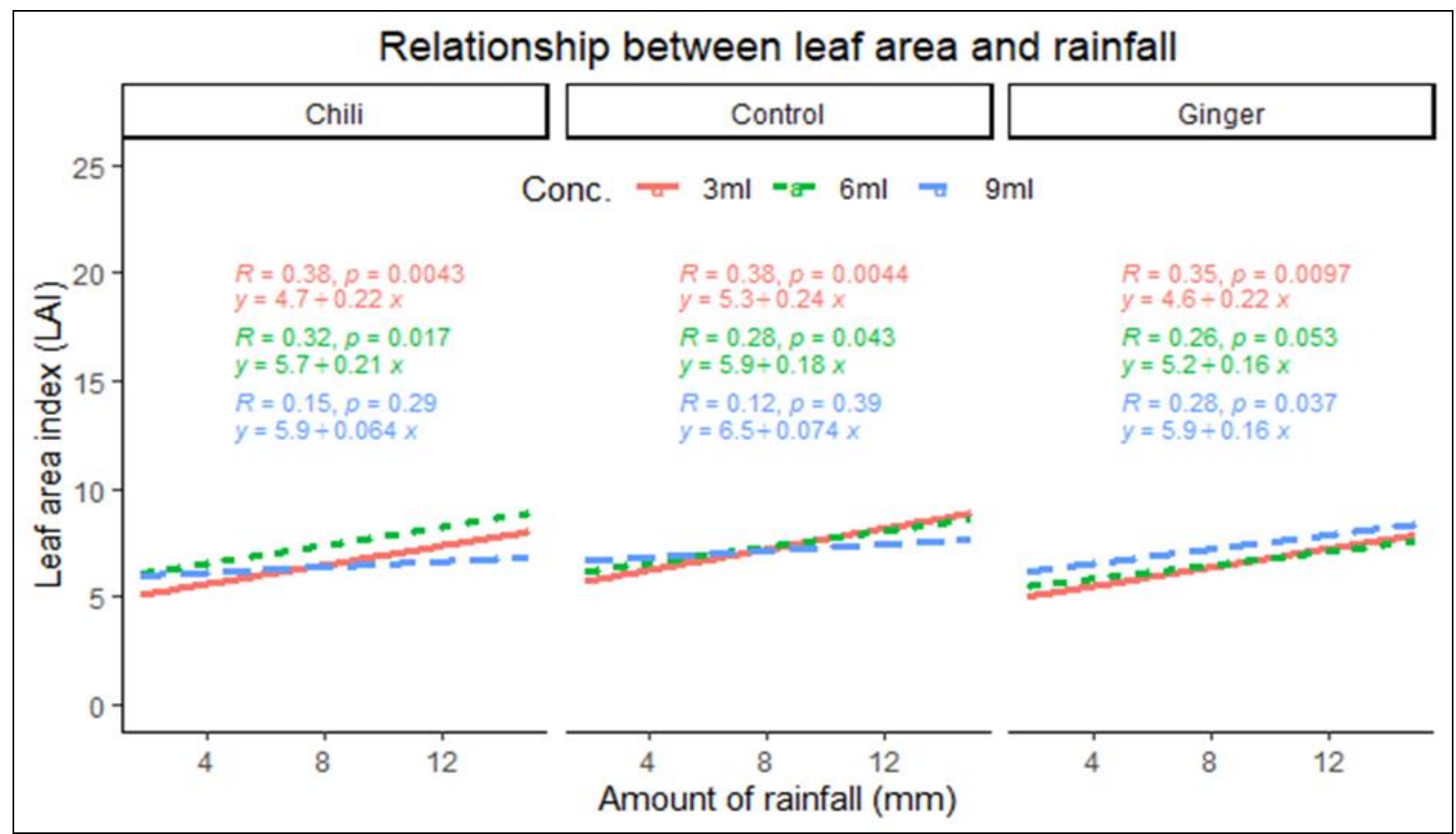

Fig 3: Leaf area index (LAI) was positively correlated with rainfall. There was an increasing trend in terms of LAI in chili, ginger and control treatments as a function of rainfall $(\mathrm{mm})$. All relationships were created using Pearson correlation $(\mathrm{R})$ with $\mathrm{p}$-values indicating the level of statistical significance at $\alpha=0.05$. 
It was noted that as the amount of rainfall (mm) increased, the leaf area index (LAI) also decreased (fig. 3). There was a significant positive correlation between $3 \mathrm{ml}$ chili and LAI $(p<0.05, \mathrm{r}=0.38)$. Chili $6 \mathrm{ml}$ also showed a significant positive correlation with LAI $(p<0.05, \mathrm{r}=0.32)$. Chili $9 \mathrm{ml}$ had a weak non-significant relationship with LAI $(p>0.05, \mathrm{r}$ $=0.15)$. Both $3 \mathrm{ml}$ and $6 \mathrm{ml}$ control treatments had positive significant correlation with LAI while $9 \mathrm{ml}$ was nonsignificant. Ginger showed significant positive relationship at $3 \mathrm{ml}$ and $9 \mathrm{ml}$ while $6 \mathrm{ml}$ was non-significant.

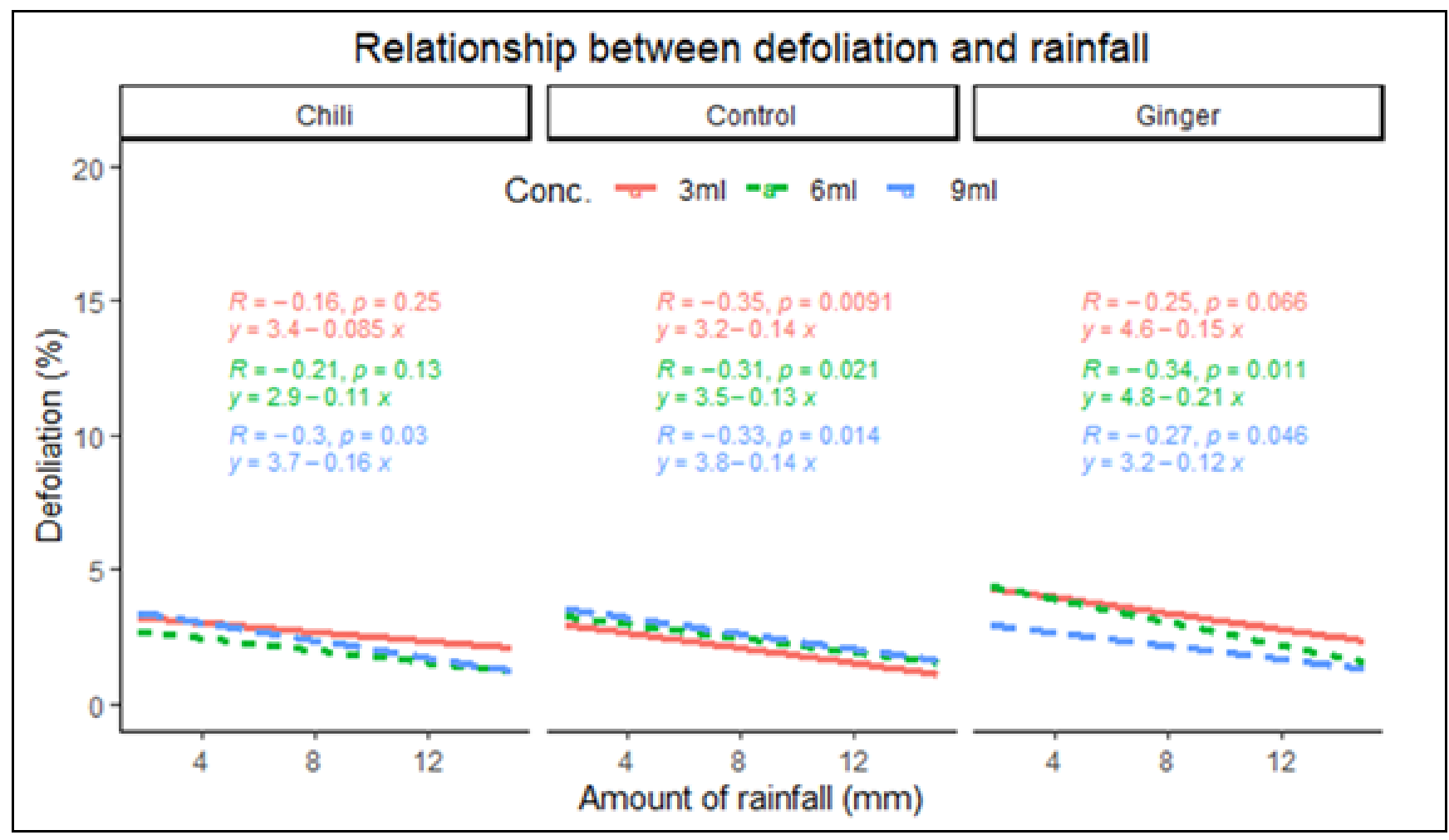

Fig 4: Defoliation (\%) was negatively correlated with rainfall. A decreasing trend in terms of defoliation in chili, ginger and control treatments was noted as rainfall $(\mathrm{mm})$ increased. All relationships were created using Pearson correlation $(\mathrm{R})$ with p-values indicating the level of statistical significance at $\alpha=0.05$.

Defoliation $(\%)$ of cabbage leaves decreased as the amount of rainfall $(\mathrm{mm})$ increased (fig .4). As rainfall increased, defoliation significantly decreased in chili $9 \mathrm{ml}(p<0.05, \mathrm{r}=$ -0.3). Both $3 \mathrm{ml}$ and $6 \mathrm{ml}$ chili showed weak negative relationship with increasing rainfall. All concentration levels of control treatment had significant negative correlation with defoliation. As rainfall increased, it reduces defoliation in cabbage plants. The negative correlation was significant in $6 \mathrm{ml}(p<0.05, \mathrm{r}=-0.25)$ and $9 \mathrm{ml}(p<0.05, \mathrm{r}=-0.27)$ ginger. Ginger $3 \mathrm{ml}$ did not show any significant relationship in terms of defoliation versus rainfall.

\section{Discussion}

The results showed that chili extract (Capsicum frutescens) was effective at lower concentrations $\left(3 \mathrm{ml} \mathrm{L}^{-1} v / v\right.$ and $6 \mathrm{ml}$ $\left.\mathrm{L}^{-1} v / v\right)$ than at higher dose $\left(9 \mathrm{ml} \mathrm{L} \mathrm{L}^{-1} v / v\right)$. According to a study by Iamba and Malapa (2020) ${ }^{[21]}$, chili extract was effective in controlling $P$. xylostella. Due to its antifeedant and repellent properties, chili extract have proven to be an effective botanical pesticide (Iorizzi et al. 2000; Khan et al. 2000; Iamba \& Yoba 2019) [23, 25, 20]. Cabbages that were sprayed with chili extract were able to produce good yield (Begna \& Damtew 2015) ${ }^{[5]}$. Chili $6 \mathrm{ml}$ was able to provide better protection to cabbage leaves therefore the defoliation is significantly lower than ginger and control treatment. In the absence of chili extract, $P$. xylostella caused notable defoliation to cabbage plants and damage severity was high (Reuben et al. 2006) [34]. Chili contains active phytochemical family of capsaicinoids, diterpenoids, flavonoids, saponins, and phenolic compounds which are lethal against insect pests including $P$. xylostella (Iorizzi et al. 2000; Madhumathy et al. 2007; Begna \& Damtew 2015) $[23,27,5]$. Studies on chili extract showed that it is compatible with natural enemies of $P$. xylostella at application rate of $10 \mathrm{ml} \mathrm{L}^{-1} v / v$ (Iamba \& Yoba 2019) ${ }^{[20]}$. Since predators such as W. auropunctata $\mathrm{R}$ and Epilachna spp consumes their prey whole, therefore they are most succumb to the toxicity of chemical pesticides (Theiling \& Croft 1988) ${ }^{[39]}$.

On the other hand, ginger extract was effective at higher concentration $\left(9 \mathrm{ml} \mathrm{L}^{-1} v / v\right)$ than at lower doses $\left(3 \mathrm{ml} \mathrm{L}^{-1} v / v\right.$ and $\left.6 \mathrm{ml} \mathrm{L}^{-1} v / v\right)$. Ginger is considered a repellent plant that can be incorporated into a push system to discourage oviposition (Liu et al. 2007) ${ }^{[26]}$. According to an experiment carried out by Iamba and Masu (2020) ${ }^{[21]}$, ginger (Zingiber officinale) was effective in reducing oviposition than marigold extract. Ginger contains insecticidal compounds such as arcurcumene, b-myrcene, 1,8-cineole, citral, and zingiberene which helps as repellents and deterrents against insect pests (de Melo et al. 2011; Bayala et al. 2014; Hamada et al. 2018) [9, 4, 15]. The volatile chemical constituents of ginger extract have proven to deterred insect pests (Escoubas et al. 1995; Agarwal et al. 2001) ${ }^{[10,2]}$. The antifeedant property of ginger extract disrupted the growth activity of Spodoptera litura F larvae1 (Sahayaraj \& Sekar 1996; Sahayaraj 1998) ${ }^{[36,35] .}$

Our study showed mix results on the effectiveness of chili at the lowest $\left(3 \mathrm{ml} \mathrm{L}^{-1} v / v\right)$ and highest dose $\left(9 \mathrm{ml} \mathrm{L}^{-1} v / v\right)$ which can be subjected to few factors. This result supports 
an experiment by Ishii et al. (2010) ${ }^{[24]}$, where the repellent activity of chili against $S$. zeamais $\mathrm{L}$ adults were unverified and had weak repellent activity. Neem extract provided the highest repellent effect against pests of dried fish followed by chili (Nowsad et al. 2009) ${ }^{[29]}$. Rainfall had a significant effect on abundance of $P$. xylostella, leaf area and defoliation. Plant extracts applied on foliar can be washed away by heavy rains and are constantly being exposed to other adverse weather conditions such as humidity and temperature (Iamba \& Masu 2020) ${ }^{[21]}$. However for this study, relative humidity and temperature did not have any significant effect on ginger and chili extracts. We assume $9 \mathrm{ml}$ chili to be too toxic to natural enemies therefore abundance and defoliation did not significantly differ from control treatments. Under increasing rainfall, $6 \mathrm{ml}$ chili contributed to low defoliation (\%) and was able to produce high LAI (fig. 3). Increasing rainfall did not have any significant effect on abundance of $P$. xylostella at $6 \mathrm{ml}$ chili. Concurrently, ginger $9 \mathrm{ml}$ produced high LAI, low defoliation and low abundance of $P$. xylostella in spite of increasing rainfall (fig. 4).

\section{Conclusion}

Local spice plants such as chili and ginger are locally available and can be readily utilized to manage insect pests in crops. From this study, $6 \mathrm{ml}$ chili contributed to low defoliation (\%) and was able to produce high LAI regardless of increasing rainfall (fig. 3). Ginger 9ml produced high LAI and low defoliation in spite of increasing rainfall (fig. 4). Further study can look into quantifying natural enemies (i.e. predators/parasitoids) at each concentration levels and determining their compatibility. Referencing from previous studies, chili is an effective botanical extract however further investigation can test for more concentration levels in order to reach a point of equilibrium between $P$. xylostella and natural enemies. Weather parameters such as rainfall, humidity and temperature also influence the dynamics of plant attack and needs to be taken into consideration.

\section{Acknowledgments}

We are grateful for the input and contribution of $\mathrm{Mr}$ Solomon Yoba and Miss Sandrina Malapa for their initial studies into botanical extracts in Vudal agroecosystem. Their valuable contributions set the platform for this study to launch. We extend our appreciation to nursery staff of PNG UNRE for supplying the cabbage seedlings for this study.

\section{References}

1. Abbasipour H, Mahmoudvand M, Rastegar $\mathrm{F}$ et al. Insecticidal activity of Peganum harmala seed extract against the diamondback moth, Plutella xylostella. Bull Insectol 2010;63:259-263.

2. Agarwal M, Walia S, Dhingra S et al. Insect growth inhibition, antifeedant and antifungal activity of compounds isolated/derived from Zingiber officinale Roscoe (ginger) rhizomes. Pest Management Science: formerly Pesticide Science 2001;57:289-300.

3. Agelopoulos N, Birkett MA, Hick AJ et al. Exploiting semiochemicals in insect control. Pesticide science 1999;55:225-235.

4. Bayala B, Bassole IHN, Gnoula C et al. Chemical composition, antioxidant, anti-inflammatory and anti- proliferative activities of essential oils of plants from Burkina Faso. PLoS one 9, e92122, 2014.

5. Begna F, Damtew T. Evaluation of four botanical insecticides against Diamondback Moth, Plutella xylostella L. (Lepidoptera: Plutellidae) on head cabbage in the central rift valley of Ethiopia. SJAR 4, 2015, 97105.

6. Charleston DS, Kfir R, Dicke M et al. Impact of botanical pesticides derived from Melia azedarach and Azadirachta indica on the biology of two parasitoid species of the diamondback moth. Biological control 2005;33:131-142.

7. Chen CC, Chang SJ, Hou R et al. Deterrent effect of the chinaberry extract on oviposition of the diamondback moth, Plutella xylostella (L.) (Lep., Yponomeutidae). Journal of Applied Entomology 1996;120:165-169.

8. Coulibaly O, Mbila D, Sonwa D et al. Responding to economic crisis in sub-Saharan Africa: New farmerdeveloped pest management strategies in cocoa-based plantations in Southern Cameroon. Integrated Pest Management Reviews 2002;7:165-172.

9. De Melo GAN, Grespan R, Fonseca JP et al. Inhibitory effects of ginger (Zingiber officinale Roscoe) essential oil on leukocyte migration in vivo and in vitro. Journal of natural medicines 2011;65:241-246.

10. Escoubas P, Lajide L, Mizutani J. Termite antifeedant activity in Aframomum melegueta. Phytochemistry 1995;40:1097-1099.

11. Fening K, Amoabeng B, Adama I et al. Sustainable management of two key pests of cabbage, Brassica oleracea var. capitata L. (Brassicaceae), using homemade extracts from garlic and hot pepper. Organic agriculture 2013;3:163-173.

12. Fening $\mathrm{K}$, Owusu-Akyaw $\mathrm{M}$, Mochiah $\mathrm{M}$ et al. Sustainable management of insect pests of green cabbage, Brassica oleraceae var. capitata L. (Brassicaceae), using homemade extracts from garlic and hot pepper, 2011.

13. Gentz MC, Murdoch G, King GF. Tandem use of selective insecticides and natural enemies for effective, reduced-risk pest management. Biological Control 2010;52:208-215.

14. Govindarajan M. Larvicidal and repellent properties of some essential oils against Culex tritaeniorhynchus Giles and Anopheles subpictus Grassi (Diptera: Culicidae). Asian Pacific Journal of Tropical Medicine 2011;4:106-111.

15. Hamada H, Awad M, El-Hefny $\mathrm{M}$ et al. Insecticidal activity of garlic (Allium sativum) and ginger (Zingiber officinale) oils on the cotton leafworm, Spodoptera littoralis (Boisd.) (Lepidoptera: Noctuidae). African entomology 2018;26:84-94.

16. Howcroft N. The balsa manual: techniques for establishment and the management of balsa (Ochroma lagopus) plantations in Papua New Guinea. ITTO East New Britain Balsa Industry Strengthening Project PD 2002;7:99.

17. Iamba K, Malapa S. Efficacy of selected plant extracts against diamondback moth (Plutella xylostella L.) on round cabbage in situ. Journal of Entomology and Zoology Studies 2020;8:1240-1247.

18. Iamba K, Masu H. An integrated approach of managing Conopomorpha cramerella Snellen: Application of 
plant extracts in a push-pull system. Journal of Entomology and Zoology Studies 2020;8:1040-1046.

19. Iamba K, Yaubi T. Incorporating lemon grass (Cymbopogon citratus L.) and marigold (Tagetes erecta L.) as non-host barrier plants to reduce impact of flea beetle (Chaetocnema confinis C.) in cabbage (Brassica oleracea var. capitata L.). Acta Entomology and Zoology 2021;2:95-101.

20. Iamba K, Yoba S. Compatibility of Predators and Botanical Extracts against Plutella xylostella on round cabbage. IOSR Journal of Agriculture and Veterinary Science (IOSR-JAVS) 2019;12:64-68.

21. Iamba K, Yoba S. Spatio-temporal dispersion patterns of Bactrocera musae Tryon (Diptera: Tephritidae: Dacinae) in Vudal agroecosystem, East New Britain. International Journal of Entomology Research 2020;5:78-84.

22. Iamba K, Yoba S, Wolokom B et al. Habitat selection by fruit flies (Diptera: Tephritidae) in a tropical agroecosystem in Papua New Guinea 2021.

23. Iorizzi M, Lanzotti V, Trematerra $\mathrm{P}$ et al. Chemical components of Capsicum annuиm L. var. acuminatum and their activity on stored product insect pests. In: Proceedings-Phytochemical Society of Europe. Dordrecht; London; Kluwer Academic Publishers, 1998, 2000, 77-86.

24. Ishii T, Matsuzawa H, Vairappan CS. Repellent activity of common spices against the rice weevil, Sitophilus zeamais Motsch (Coleoptera, Curculionidae). Journal of Tropical Biology \& Conservation (JTBC), 2010.

25. Khan ZR, Pickett JA, Berg Jvd et al. Exploiting chemical ecology and species diversity: stem borer and striga control for maize and sorghum in Africa. Pest Management Science: Formerly Pesticide Science 2000;56:957-962.

26. Liu SS, Li YH, Lou YG. Non-host plant extracts reduce oviposition of Plutella xylostella (Lepidoptera: Plutellidae) and enhance parasitism by its parasitoid Cotesia plutellae (Hymenoptera: Braconidae). Bulletin of Entomological Research 2007;96:373-378.

27. Madhumathy A, Aivazi AA, Vijayan V. Larvicidal efficacy of Capsicum annum against Anopheles stephensi and Culex quinquefasciatus. Journal of Vector Borne Diseases 2007;44:223.

28. Miller JR, Cowles RS. Stimulo-deterrent diversion: a concept and its possible application to onion maggot control. Journal of chemical ecology 1990;16:31973212.

29. Nowsad A, Mondal R, Islam M. Effectiveness of neem, garlic and red chili against adult dermestid beetle in sun dried fish. Progressive Agriculture 2009;20:133-142.

30. Ntow WJ, Gijzen HJ, Kelderman $\mathrm{P}$ et al. Farmer perceptions and pesticide use practices in vegetable production in Ghana. Pest Management Science: formerly Pesticide Science 2006;62:356-365.

31. Obeng-Ofori D, Ankrah D. Effectiveness of aqueous neem extracts for the control of insect pest cabbage (Brassica oleracea var capitata L.) in the Accra plains of Ghana. Agricultural and Food Sciences Journal of Ghana 2002;1:83-94.

32. Pickett J, Wadhams L, Woodcock C. Developing sustainable pest control from chemical ecology. Agriculture, ecosystems \& environment 1997;64:149156.
33. Pyke B, Rice M, Sabine B et al. The push-pull strategybehavioural control of Heliothis. Australian Cotton Grower 1987;9:7-9.

34. Reuben S, Yahya SN, Misangu RN et al. Field evaluation on effects of common spices in the control of diamondback moth (Plutella xylostella L.) pest of Chinese cabbage (Brassica campestris L.) commercial cultivar. Asian Journal of Plant Sciences 2006;5:85-90.

35. Sahayaraj K. Antifeedant effect of some plant extracts on the Asian armyworm, Spodoptera litura (Fabricius). Current Science 1998, 523-525.

36. Sahayaraj K, Sekar R. Efficacy of plant extracts against tobacco caterpillar larvae in groundnut 1996.

37. Saripah B, Hajjar MN, Alias A et al. Inhibitory effect of Zingiberaceae essential oils against Conopomorpha cramerella (Snellen) Lepidoptera: Gracillariidae. Journal of the Bangladesh Agricultural University 2019;17:349-354.

38. Shin-Foon C, Yu-Tong Q. Experiments on the application of botanical insecticides for the control of diamondback moth in South China. journal of applied entomology 1993;116:479-486.

39. Theiling KM, Croft B. Pesticide side-effects on arthropod natural enemies: A database summary. Agriculture, Ecosystems \& Environment 1988;21:191218.

40. Timbilla J, Nyarko K. A survey of cabbage production and constraints in Ghana. Ghana Journal of Agricultural Science 2004;37:93-101.

41. Zhang S, Zhang X, Shen J et al. Susceptibility of field populations of the diamondback moth, Plutella xylostella, to a selection of insecticides in Central China. Pesticide biochemistry and physiology 2016;132:38-46. 